\title{
Emerging Issues in Education and Family the Effect of Parental Social Support on Career Decision Making Self-Efficacy
}

\author{
Ferdi Sapan Alextian ${ }^{1, *}$ Sri Muliati Abdullah ${ }^{2}$ \\ 1,2 University of Mercu Buana Yogyakarta 1 \\ *Corresponding author.Email:ferdisapan.27@gmail.com \& srimuliati@mercubuana-yogya.ac.id
}

\begin{abstract}
Every year senior high school students are confronted with the career decision associated with college majors. Many senior students are unsure of the selected college choices because of the lack of social support from parents. This study aims to determine the effect of parental support on career decision making self-efficacy (CDMSE) of the XII high school students. The hypotheses in this study is suspected that there is an effect of parental support on career decision making self-efficacy. The population in this study is a XII-grade high school student of SMA 1 Toraja Utara and SMA 2 Toraja Utara with sample number of 217 students in which there were 82,94\% (180) female and $17,05 \%$ (37) male students, ranging from 16 to 19 years of age. Data was collected using a questionnaire compiled in Google form and distributed online. Data was analysed using the IBM SPSS statistics 23 software. Regression tests indicated that parental support had a significant impact on the career decision making self-efficacy with a value of $\mathrm{t}=10,311(\mathrm{p}<0.05)$. Parental social support influenced students' high career decision making self-efficacy.
\end{abstract}

Keywords: Parental support and career decision making self-efficacy (CDMSE), XII-grade high school student.

\section{INTRODUCTION}

The college final high school student selection is one of the issues that emerged in the educational world that is still interesting to discuss. According to government regulation (PP) no. 17 in 2010, chapter 76 verse 1 that the function and purpose of high school is to increase the physical and mental preparedness of students to further education to the higher ranks and or to live independently in communities. Judging from the function and purposes of the high school, the high school career decision after graduating from its ideal school is that students already have a high degree of self-instruction in establishing appropriate career choices when continuing college studies. But in reality not all student at the end of secondary education can easily make a career decision, many of them experience a phase of doubts before they are settled on a career path [1]. This can happen in view of the many possible alternate courses in college that students can choose. Some senior high school students choose a course in college because they have good grades at the lesson but are not necessarily interested in it, and they just follow a friend who chooses what he or she is, chooses what he or she will be, or follow their parents' advice. According to Kasali [2], parents should avoid meddling too far, simply being a facilitator and giving consideration, and being open and following the age. Then the student needs to be left to make their own choices and be accountable for the choices they take.

Sarwono in [3] observes the same symptoms year after year in Indonesia, a graduate at public secondary school, did not know where to go. Research was also found on one of the Startubing company Skystar Ventures, tech incubator Multimedia Nusantara University (UMN) which is youth manual (at www. kompasiana.com on April 11, 2018) research on 400,000 student data profiles throughout Indonesia found fact that $92 \%$ student of SMA/SMK were confused and do not know what the future will be. 
Germeijs and Verschueren [4] pose the effects on individual lives in the future when choosing a major program is wrong, which is: a) psychological problems, choosing an objectionable subject, such as parenting choices, following friends or trends can lower resistance to pressure, concentration, and fighting. b) escape problems, such as bullying by the compensation of your inferiority in studies, such as feelings of discomfort, insecurity, being quiet, withdrawing from one's associates, preferring solitude in a room, and being afraid of others. c) academic problems, such as unoptimal achievements, difficulty in understanding materials and problem solving, inability to study alone, many retaking courses that impact more time and cost and can influence learning motivations and attendance rates that lead to lower performance index value.

To be able to make independent career decisions, youth need confidence that they have the ability, skills, and capacity to analyse existing information as considerations for making career decisions [5]. Such confidence is also called career decision making selfefficacy (CDMSE). [6]Career decision making selfefficacy is an individual's confidence in its ability to perform the duties associated with career decision making.

In formulating the scale of a Career decision making Self-Efficacy in the dimensions presented by [7] as level (difficulty), generality (area wide), and strength (strength level). The writer chose this theory because it is the basic concept of self-efficacy. In the autonomous scale of Career decision making SelfEfficacy, using the domain-specific approach to the one-part sub theme. The sub theme used is the aspect of a Career decision making Self-Efficacy [6], that is, self-assessment, career information gathering, goal selection, planning, and problem solving. This aspect is a relevant domain of behavior with the process of career decision making defined as behavior that indicates the five joint-choice competency [6].

In cognitive social theory, self-efficacy assessments are formed based on four sources of learning experiences: a) attainment of personal performance, b) learning through models, c) emotional support from others, and d) the verbal drive of others [8]. This explains how external factors play a role such as parental support in improving student growth. Caprara, Scabini, and Regauls [3] suggested that a self-efficacy did not come by itself but was the result of sharing knowledge and responsibility, diverse relationships, beneficial duties, and interactions with others. In building confidence in youth abilities and capacities to make career decisions, youth need parental support [9]. [11] states that social support is the physical and psychological comfort of a friend or family member. Social support can also be seen in the multitude of social contacts that individuals make in connecting to existing resources in the ward. [10] comes to the conclusion, social support is the comfort, care, appreciation, or assistance that is available to one person from another person or group. Referring to the opinions of [11] and [10] parental support can be defined as the assistance parents provide to adolescents in the form of physical and psychological comfort such as concern, appreciation. Aspects of parental support refer to those of social support [12] which are emotional support, instrumental support, informational support, reward. From the parent's support, students may discern that the help given by the parent can benefit him or her. The individual's perceived support of those most influential is more likely to have a more direct influence on the selfefficacy in the decision making of other contextual factors [15]. The theoretical perspectives of this study can be learned more detail through the social cognitive career theory (SCCT) that offer more support by offering an in-depth knowledge of how parental support is relevant to Career decision making SelfEfficacy. As the SCCT explains, individual autonomy and perceptions for dealing with problems or obstacles can be positive or negative. Environment or contextual event influence one's confidence or autonomy through self-regulation. Links between parental support and the Career decision making Self-Efficacy have also been demonstrated by a number of previous studies. To support this, an earlier study has reported that 29 percent to 43 percent of total variances in a vocational self-extension are recorded through perception of parental support [14].

Research [15] shows that the career-related support influences a direct career decision-making effort. A similar finding is expressed by Xing and Rojewski [16] who have found that parental support is statistically significant factor in predicting a career decision-making process. Ginevra, Nota, and Ferrari [17] in their research claim that parents must be involved early in vocational or career development. [5] 
state that the role of parents toward youth selfpromotion in making career decisions can be seen from parental efforts to encourage youth to follow a parent's career or pursue a career recommended by parents. The individual's support becomes a guide or grip for confidence in his/ her choice in the process of his/her career development.

When a student is convinced of his/her career decision, it will impact the student's career decision making. [18]Mention that career decision making selfefficacy is a factor in fuelling career decision. Previous studies state that there is a positive and significant relationship between self-efficacy and the ability to make career decisions in youth [19] Based on the exposure of the above study, the authors are interested in investigating how parental support affects decision making of XII-grade high school students.

\section{METHOD}

This study employed a quantitative research method. The research population was the XII-grade of SMA 1 and SMA 2 of Toraja Utara, South Sulawesi. Research data collection was achieved by disseminating a questionnaire to the subject online. 217 students filled out questionnaires, which comprised $82,94 \%$ (180) female and $17,05 \%$ (37) male students ranging from 16 to 19 years of age.

The Likert scale for this research measured: 1) Self-efficacy scale of career decision made by domainspecific in reference to dimensions [7] and aspects [6] with the correct item [6] with the validity of correct item ranging from 0.289 to 0.67 with the coefficient Cronbach's alpha of 0.915. 2) Parental Support scale was set up by referring to the aspect of [11] with the correct item from 0.307 to 0.728 with the coefficient Cronbach's alpha of 0.918. Regression analysis was performed to test the research hypothesis.

\section{RESULT}

The results of a descriptive statistical analysis can be viewed in Table 1 .

Table 1. Graphic results

\begin{tabular}{lcllll}
\hline & $\mathrm{N}$ & Min & Max & Mean & SD \\
\hline DO & 217 & 64 & 123 & 99,08 & 12,738 \\
CDMSE & 217 & 96 & 164 & 131,44 & 14,53 \\
\hline
\end{tabular}

Table 1 showed that data from the subject's 217 (n $=217$ ) pointed out that a parent's support scale had a minimum of 64 and maximum value of 123 , an average value of 99.08 with SD 12.7 738. Then on the scale of a Career decision making Self-Efficacy, a minimum value of 96 and maximum value of 164, an average of 131.44 with SD 14.53

Based on the residual normality test with Kolmogorov-Smirnov showed a significant data distribution $(p=0.200)$. This meant that data was distributed normally. The regression analysis was summarised in Table 2.

Table 2. Regression analysis results

\begin{tabular}{llllll}
\hline Model & $\mathbf{R}^{2}$ & $\mathbf{B}$ & $\mathbf{t}$ & $\mathbf{P}$ & Note \\
\hline $\begin{array}{l}\text { DO } \rightarrow \\
\text { CDMSE }\end{array}$ & 0,331 & 0,653 & 10,311 & 0,000 & Sig.
\end{tabular}

Hypothetical tests indicate that there has been an effect of parental support on the development of a career decision. This finding was supported by previous studies. For example, Ali and Mukhibat [20] found that family support had significant and positive effects on the Career decision making Self-Efficacy. Xing and Rojewski [16] also showed that parental support was a significant factor in predicting a Career decision making Self-Efficacy. 17]suggested that parents should be involved early in the development or individual careers. Parental support and upbringing can enhance career exploration and positively relate to the self-efficacy of an individual in selecting his/her career [21]. The study was supported by Lent, Brown, \& Hackett, in [22] who claimed that people with high self-efficacy tend to visualise positive results regarding specific tasks they perform. The implication is that individual can focus on fulfilling their goals which means deciding career path they choose.

Other research findings suggest that parental support facilitates the development of career decision making self-efficacy that affects the individual decisions [22]. Ferry, Fouad, and Smith [23] explained that parental supports (emotional support, encouragement, hope, and general guide) and parental career specific behaviours, such as giving written career information to individuals had influence in increasing self-efficacy in individual career decision making. Such supports may help individuals to believe 
that they can accomplish work-related tasks and decision making.

\subsection{Discussion}

Social support from parents is thought to be a correlation with career decision making self-efficacy. Individuals who gain high parental support will thus have much emotional, rewarding, instrumental, and informative support from the family. When emotional support is high, the individual feel that he/she is strongly encouraged by his/her parents. When appreciation for the individual is achieved, this increases his/her confidence. When the individual gains instrumental support, he/ she feels that he/she has adequate parental support. When the individual has rich informative support, he/she feels that he/she receives attention and knowledge. A self-efficacious person will know about staying in the job until he/she succeeds. In contrast, individuals who develop a low self-efficacy attitude may have a pessimistic attitude, difficult to determine wn destiny, a yielding spirit when facing difficult situations and low commitment to set goals [7].

Parental support also has a direct influence on the development of career decision making. Based on social cognitive theory [7], self-efficacy resources can be obtained, studied or grown from contextual support resources (parents, friends, school, etc.) through social persuasion and social learning. A previous study [22] demonstrates that parental support can be useful in promoting a career environment by providing verbal encouragement, information suggestions, and practical support. Caprara, Scabini, dan Regalia in [3] suggest that self-efficacy is a result of sharing knowledge and responsibility, diverse relationships, beneficial duties, and interactions with others.

[23] note that parental supports (such as emotional support, encouragement, hope, and general guide) and parental career specific behaviours, such as giving written career information to individuals have influence in increasing Career decision making selfefficacy. These enable individuals to believe that they can accomplish the tasks related to his work plan and decision making. Parents and teachers can provide instrumental supports (such as financial assistance; School-related advice) to facilitate performance achievement (for example, higher grades at school), as described by [24]. [24] Other sources of supports can contribute to the growth of a self-efficacy career decision through emotional support and verbal encouragement in dealing with challenges and difficulties.

[5] contend that the role parents play on the selfefficacy of teenagers in making career decisions can be viewed from parents' efforts to encourage teenagers to follow parent's career or pursue a career recommended by parents. Individuals who have had the support of parents tend to have high Career decision making self-efficacy. This can be achieved by increasing frequency of communication and implementing effective communication strategies (for example, memorandum and teacher dialogue) that will allow parents and teachers to identify the needs and difficulties of the more customised intervention program [24]. In other words, parents should not only ensure that they support their children (for example, help select a university and talk to their children about possible careers), but parents should also encourage their children to seek out and use support services at their school such as career counselling.

We would also like to note that counsellors, parents, and teachers should be vigilant for being potentially over-supportive that may produce unrealistic and overconfident positive expectations. Being overly optimistic and persistent about a career without skills necessary to really engage in adaptive behaviour can result in setting unrealistic goals and views of success[26].

The findings of this study suggest that intervention should focus on increasing four sources of effort information (performance, proxy learning, management of emotional arousal, and verbal persuasion to significantly predict the self-efficacy Bandura in [[27]. For example, [28] found that providing instrumental assistance by parents, modelling for careers, emotional support, and verbal compulsiveness are important to build teen confidence in successfully completing the tasks associated with academic and career planning. By focusing on selfindulgence, students are not only optimistic about their future, they also have skills necessary to adapt to the context of a changing career landscape.

Student with a high degree of self-efficacy in his/her career decision making indicates that he/she has made a proper career decision and has made a 
confident decision related to which courses the student will continue for his/her further study for his/her career. While student with a low self-efficacy in career decision making tend to find difficulty in thinking of one precise advanced study which will be tackled later and tend to enter subjects of study that do not fit to their expectations and abilities.

The findings recommend that parental involvement from an early age helps students to introduce careers, direct and provide support. Students should be helped to be aware of the importance of planning and choosing a career. As students become more independent and responsible in deciding their careers, parents play a role in building students' confidence in deciding their career. This is important so that students do not have doubts about their career choices. Building interactions with children, finding information about careers and providing social supports are some strategies parents can develop their children's self-efficacy career decision making.

\section{2 Conclusion}

High self-efficacy assists students in dealing with and resolving problems that are currently encountered. Self-efficacy also helps students achieve a reachable goal. Self-efficacy can determine a person's success in achieving his/her desired goal. The results of this study indicate that there is an effect of parental support on career decisions making self-efficacy of class XII students. To increase students' self-efficacy career decision making, they need parental social support.

\section{AUTHORS' CONTRIBUTIONS}

The first author's contribution to this study was to conduct field assessments, make item scales, test and analyse the quality of the scale, the results of statistical analysis were discussed and written in the research report. These contributions are interlinked and synergized with the contributions of the second author. In this study, the second author's contribution is to conduct a critical analysis of the results of the assessment of field problems conducted by the first author, to analyse the contents of the scale items and the results of the scale quality psychometric analysis, to conduct a critical analysis of the results and discussion.

\section{ACKNOWLEDGMENTS}

Praise be to the Almighty God for His favour so that the writing of this article can be completed. The author thanks the organisers of the International Virtual Conference on Psychological Studies (ICPSYCHE) who has provided opportunity to publish the author's scientific literature. The writer also thanked the counsellor who helped with the entry of the article.

\section{REFERENCES}

[1] P. Creed, W. Patton, and L. A. Prideaux, "Causal relationship between career indecision and career decision-making self-efficacy: A longitudinal cross-lagged analysis," J. Career Dev. 33(1) (2006) 47-65.

[2] L. Rossallina and R. A. Salim, "Perilaku eksplorasi karier, dukungan sosial, dan keyakinan dalam pengambilan keputusan karier SMP," Pers. Psikol. Indones. 8(2) (2019) 224239.

[3] D. R. Sawitri, "Pengaruh Satatus Identitas dan Efikasi Diri Keputusan Karier terhadap Keraguan Mengambil Keputusan Karir pada Mahasiswa Tahun Pertama di Universitas Diponegoro," J. Psikol. Undip. 5(2) (2009).

[4] V. Germeijs and K. Verschueren, "High school students' career decision-making process: Consequences for choice implementation in higher education," J. Vocat. Behav. 70 (2007) 223-241.

[5] D. R. Sawitri, P. A. Creed, and M. J. ZimmerGembeck, "Parental influences and adolescent career behaviours in a collectivist cultural setting," Int. J. Educ. Vocat. Guid. 14(2) (2014) 161-180.

[6] K. M. Taylor and N. E. Betz, "Applications of self-efficacy theory to the understanding and treatment of career indecision," J. Vocat. Behav. 22(1) (1983) 63-81.

[7] A. Bandura, "Self-Efficacy: The exercise of control," Self-efficacy: The exercise of control. W.H. Freeman and Company, New York. 1997. p.3.

[8] R. W. Lent, S. D. Brown, and G. Hackett, "Contextual supports and barriers to career choice: A social cognitive analysis," J. Couns. Psychol. 47(1) (2000) 36-49.

[9] H. L. S. Tien, C. H. Lin, and S. C. Chen, “A grounded analysis of career uncertainty perceived by college students in Taiwan," Career Dev. Q. 54(2) (2005) 162-174.

[10] B. N. Uchino, Social support and physical health: Understanding the health consequences 
of relationships. New Haven and London: Yale University, 2004.

[11] B. Smet, Psikologi Kesehatan. Jakarta: Grasindo, 1994.

[12] R.A. Baron, D. Byrne. Psikologi Sosial. Edisi kesepuluh: jilid 2. Jakarta: Erlangga, 2005.

[13] S. L. Wright, K. M. Perrone-Mcgovern, J. N. Boo, and A. V. White, "Influential factors in academic and career self-efficacy: Attachment, supports, and career barriers," J. Couns. Dev. 92(1) (2014) 36-46.

[14] R. T. Turner, Sherri, Lapan, "Career self-efficacy and perceptions of parent support in adolescent career development," Career Dev. $Q$. 51(September) (2002) 44-55.

[15] D. S. Amini and R. M. A. Salim, "Dukungan Orangtua, Efikasi Diri Pengambilan Keputusan Karier, Dan Planned Happenstance Pada Siswa Sekolah Menengah Pertama," J. Psikol. Ulayat, 7(1) (2020) 87-98.

[16] X. Xing and J. Rojewski, "Family Influences on Career Decision-Making Self-Efficacy of Chinese Secondary Vocational Students.," New Waves-Educational Res. Dev. J. 21(1) (2018) 48-67.

[17] M. C. Ginevra, L. Nota, and L. Ferrari, "Parental support in adolescents' Career development: Parents' and children's perceptions," Career Dev. Q. 63(1) (2015) 2-15.

[18] V. Germeijs, K. Luyckx, G. Notelaers, L. Goossens, and K. Verschueren, "Choosing a major in higher education: Profiles of students' decision-making process," Contemp. Educ. Psychol. 37(3) (2012) 229-239.

[19] M. Peilouw, Florence J \& Nursalim, "Hubungan antara pengambilan keputusan dengan kematangan emosi dan self-efficacy pada remaja," Character. 1(2) (2013) 1-6.

[20] M. Ali and Mukhibat, "Dukungan Keluarga , Peran Keputusan Karir , dan Career Indecision Siswa Sekolah Madiun," Palastren. 9(2) (2016) 279-304.

[21] J. Dietrich and B. Kracke, "Career-specific parental behaviors in adolescents' development," J. Vocat. Behav.75(2) (2009) 109-119.

[22] S. L. D. Restubog, A. R. Florentino, and P. R. J. M. Garcia, "The mediating roles of career selfefficacy and career decidedness in the relationship between contextual support and persistence," J. Vocat. Behav. 77(2) (2010) 186-195.

[23] T. R. Ferry, N. A. Fouad, and P. L. Smith, "The Role of Family Context in a Social Cognitive Model for Career-Related Choice Behavior: A Math and Science Perspective," J. Vocat. Behav., 57(3) (2000) 348-364.

[24] J. Metheny, E. H. McWhirter, and M. E. O’Neil,
"Measuring perceived teacher support and its influence on adolescent career development," $J$. Career Assess. (2008) 1-20.

[25] S. L. Christenson, T. Rounds, and D. Gorney, "Family factors and student achievement: An avenue to increase students' success.," Sch. Psychol. Q. 7(3) (1992) 178-206.

[26] F. P. McKenna, "It won't happen to me: Unrealistic optimism or illusion of control?," $\mathrm{Br}$. J. Psychol. 84(1) (1993) 39-50.

[27] P. R. J. M. Garcia, S. L. D. Restubog, P. Bordia, S. Bordia, and R. E. O. Roxas, "Career optimism: THE roles of contextual support and career decision-making self-efficacy," J. Vocat. Behav., 88 (2015) 10-18.

[28] S. L. Turner, A. Alliman-Brissett, R. T. Lapan, S. Udipi, and D. Ergun, "The career-related parent support scale," Meas. Eval. Couns. Dev. 36(2) (2003) 83-94. 